\title{
Growth Substrate and Nutrient Salt Environment Alter Mannitol-to-Hexose Partitioning in Celery Petioles
}

\author{
Johan M.H. Stoop ${ }^{1}$ and David M. Pharr ${ }^{2}$ \\ Department of Horticultural Science and Plant Physiology Program, North Carolina State University, \\ Box 7609, Raleigh, NC 27695-7609
}

\begin{abstract}
Additional index words. Apium graveolens, electrical conductivity, hydroponics, mannitol oxidation, polyol, salt stress, sucrose, osmoregulation, phosphomannose isomerase, soilless mixture, sucrose-phosphate-synthase
\end{abstract}

\begin{abstract}
The fleshy parenchyma tissue of celery [Apium graveolens L. var.dulce (Mill.) Pers.] petioles is the major storage tissue for the sugar alcohol mannitol and for the hexoses, glucose and fructose. In this study, we found that plants grown in the soilless mixture, Promix, fertilized weekly with a nutrient solution, or grown in a hydroponic container culture, differed in carbohydrate composition. However, plant growth was not affected. Higher mannitol and lower hexose concentrations were present in petioles from plants grown hydroponically. This was true in petioles that did not differ in total soluble carbohydrate concentration. The ratio of mannitol to hexose concentration in petioles was $\approx 2$-fold higher for hydroponically grown plants compared to Promix-grown plants, and the higher ratio was maintained during the entire 12-week experimental period. Carbohydrate partitioning was also affected by petiole development within the plant. Sucrose and hexose concentrations were highest in mature petioles, whereas mannitol was relatively high in all petioles except the oldest ones. Because the mineral solution applied to the Promix-grown plants had a lower total salt concentration compared to hydroponically grown plants, we postulated that the salt concentration of the mineral solution might be an important factor affecting $\mathrm{C}$ partitioning in celery petioles. When plants were grown hydroponically at two different salt concentrations [electrical conductivity $(E C)=\mathbf{2 . 7}$ and $6.0 \mathrm{mS} \cdot \mathrm{cm}^{-1}$ ], high mannitol-to-hexose ratios were observed in celery petioles of plants grown at high salt concentration $\left(\mathrm{EC}=6.0 \mathrm{mS} \cdot \mathrm{cm}^{-1}\right)$, a result supporting the hypothesis that the salt environment might alter mannitol and hexose concentrations in a coordinated way. These data are consistent with the hypothesis that elevated mannitol levels may be a significant component of plant adjustment to salt stress, possibly adding osmotic adjustment and preventing inactivation of metabolic processes.
\end{abstract}

The sugar alcohol mannitol is the most abundant polyol in nature, occurring in bacteria, fungi, algae, lichens, and vascular plants (Bieleski, 1982; Lewis, 1984). Many higher plants are known to contain mannitol (Barker, 1955; Bourne, 1958; Trip et al., 1964; Zimmermann and Ziegler, 1975). In species such as celery, privet (Ligustrum vulgare L.), white ash (Fraxinus americana L.), and lilac (Syringa vulgaris L.), mannitol is a major photoassimilate that is translocated through the phloem and stored in various tissues (Loescher et al., 1992; Trip et al., 1963). Several physiological roles have been proposed for mannitol in higher plants. Mannitol may serve as a C storage compound (Lewis, 1984) or for storage of reducing power due to its capacity to be oxidized to its respective aldose or ketose sugar, thus generating $\mathrm{NAD}(\mathrm{P}) \mathrm{H}$ (Loescher, 1987; Stacey, 1974; Stoop and Pharr, 1992). Other proposed physiological roles include osmoregulation (Hellebust, 1976) and service as a compatible solute (Brown and Simpson, 1972; Yancey et al., 1982). Compatible solutes are thought to accumulate in the cytoplasm (Greenway and Munns, 1980), where they prevent inactivation of metabolic processes.

Celery has been used as a model system to study physiological and biochemical regulation of polyol metabolism (Davis et al.,

Received for publication 2 Apr. 1993. Accepted for publication 16 June 1993. This work was supported in part by the Belgian American Educational Foundation (to J.M.H.S.) and in part by the North Carolina Agricultural Research Service, Raleigh. We thank Sharon R. Funderburk and Rosemary B. Sanozky for technical assistance and Natalie Hubbard for helpful advice. Use of trade names does not imply endorsement of the products named nor criticism of similar ones not named. The cost of publishing this paper was defrayed in part by the payment of page charges. Under postal regulations, this paper therefore must be hereby marked advertisement solely to indicate this fact.

${ }^{1}$ Research associate.

${ }^{2}$ Professor.
1988; Loescher, 1992). The pathway of mannitol biosynthesis was first derived from celery plants (Rumpho et al., 1983) and was shown to occur in other higher plants such as privet (Loescher et al., 1992). Most studies involve pot-grown celery plants cultivated in a controlled environment such as a greenhouse. Hydroponic systems such as the nutrient film technique or container systems have proven to be very useful in studies involving manipulations of the root environment such as in salt-stress studies (Benoit et al., 1986; Tarczynski, 1993). However, for celery, it is unknown how this culture system might influence the growth, development, and physiological status of the plant.

The objective of the first study was to determine the effects of the growth substrate (soilless mixture vs. hydroponic system) on growth, development, mannitol and carbohydrate concentrations, and enzyme activities of celery. The results of this experiment suggested that the salt concentration of the growth media might be one of the factors affecting $\mathrm{C}$ partitioning in celery petioles. In a second experiment, celery plants were grown hydroponically at two nutrient solution concentrations [electrical conductivity (EC) $=2.7$ and $6.0 \mathrm{mS} \cdot \mathrm{cm}^{-1}$, which did not differ in macronutrient ratios, to test the hypothesis that salt concentration in the root environment affects carbohydrate partitioning in celery petioles.

\section{Materials and Methods}

Growth substrates and plant material. In the first experiment, celery was grown in two different growth substrates-a peat-based soilless mixture and a hydroponic system - to determine the effect of the growth substrate on plant growth, carbohydrate concentration, and enzyme activities. Celery transplants, breeding line CE201, provided by DNA Plant Technology, Oakland, Calif., were transplanted in a greenhouse (Raleigh, N.C.) with day and 
night temperatures maintained at $\approx 27$ and $18 \mathrm{C}$. Single transplants were placed into 25 -cm-diameter (6-liter) pots containing the peatbased soilless mixture Promix (Premier, N.Y.) or transferred to 20liter fiberglass tanks (5 plants/tank) containing a mineral nutrient solution (Hydroponic-1X) having an EC of $2.7 \mathrm{mS} \cdot \mathrm{cm}^{-1}$. One aerator per tank provided mixing and root-gas exchange. The nutrient solution was changed every 2 weeks. The Promix-grown plants were watered daily and fertilized once a week with a soluble fertilizer having an EC of $1.8 \mathrm{mS} \cdot \mathrm{cm}^{-1}$, whereas the hydroponically grown plants were constantly immersed in the Hydroponic-1X mineral solution. The Hydroponic-1X mineral solution contained the following macronutrients (millimolar): $10.92 \mathrm{~N} \mathrm{(100 \%} \mathrm{as} \mathrm{NO}_{3}^{-}$ ), $1.87 \mathrm{H}_{2} \mathrm{PO}_{4}^{-}, 10.27 \mathrm{~K}^{+}, 2.11 \mathrm{Mg}^{+2}, 3.71 \mathrm{Ca}^{+2}, 1.83 \mathrm{SO}_{4}^{-2}$, and 5.46 $\mathrm{Cl}^{-}$and the following micronutrients (micromolar): $92.5 \mathrm{~B}, 0.1$ Mo, 18.2 Mn, 0.8 Zn, 1.6 Cu, 0.2 Na, and 35.8 Fe. The soluble fertilizer used in the Promix treatment contained the following macronutrients (millimolar): $14.3 \mathrm{~N}\left(40 \%\right.$ as $\mathrm{NH}_{4}^{+}, 60 \%$ as $\left.\mathrm{NO}_{3}^{-}\right)$, $1.4 \mathrm{H}_{2} \mathrm{PO}_{4}^{-}, 4.2 \mathrm{~K}^{+}, 1 \mathrm{Mg}^{+2}, 1 \mathrm{SO}_{4}^{-2}$, and the following micronutrients (micromolar): 6.3 B, 0.1 Mo, 4.5 Mn, 0.4 Zn, 0.6 Cu, 16 Na, and $8.9 \mathrm{Fe}$. Before transplanting, $40 \mathrm{~mm} \mathrm{Ca}^{+2}$ (as gypsum, $\mathrm{CaSO}_{4} \cdot 2 \mathrm{H}_{2} \mathrm{O}$ ) was mixed into the Promix substrate of each $25-\mathrm{cm}$ (6-liter) pot. All plants received a biweekly foliar spray of $11 \mathrm{~mm}$ $\mathrm{Ca}^{2+}$ supplied as $\mathrm{Ca}\left(\mathrm{NO}_{3}\right)_{2} \cdot 4 \mathrm{H}_{2} \mathrm{O}$. Plants were grown for 12 weeks. Celery petioles were numbered from the outside to the inside of the plant, with petiole 1 being the outermost and oldest petiole. Petioles and leaves of Promix- and hydroponically grown plants were harvested biweekly, and fresh weight, dry weight, and leaf area were measured. Petioles were sliced and immediately frozen in liquid $\mathrm{N}_{2}$. Eight plants per treatment (two plants per replication) were analyzed at each harvest date.

In the second experiment, celery transplants were transferred to 20-liter fiberglass tanks supplied with either a Hydroponic-1X (EC $\left.=2.7 \mathrm{mS} \cdot \mathrm{cm}^{-1}\right)$ or Hydroponic-3X $\left(\mathrm{EC}=6.0 \mathrm{mS} \cdot \mathrm{cm}^{-1}\right)$ mineral solution and grown under the same greenhouse conditions as described above. The Hydroponic-3X treatment consisted of a 3fold increase of the Hydroponic-1X minerals. To study the effect of salt concentration on plant growth, two approaches can be taken. One approach is to vary the concentration of a single salt, typically $\mathrm{NaCl}$ (Ahmad et al., 1979, Greenway and Munns, 1980). A second approach is to increase all nutrient salts proportionally, so that the ratios of fertilizer ions in each treatment are equal. A potential drawback in using increments of only one salt, e.g., $\mathrm{NaCl}$, to study the effect of ionic strength of the mineral solution is that high $\mathrm{Na}^{+}$ or $\mathrm{Cl}^{-}$concentrations may result in imbalances of other minerals that might affect plant growth (Benoit et al., 1986). In the present study, the second approach was taken.

Carbohydrate analysis. Ethanolic extracts from each of the samples were used for measurements of sucrose, hexose sugars, and polyols. Procedures used for ethanolic extraction were as described by Hubbard et al. (1990). Carbohydrate content was determined on a high-performance liquid chromatography system using a $\mathrm{Ca}^{+2}$ column (Sugar-Pak I; Millipore, Waters Chromatography Div., Milford, Mass.). The column was preceded by a $\mathrm{C}_{18} /$ Corasil guard (Bondapak; Waters) and a set of anion and cation cartridges (BioRad, Richmond, Calif.).

Carbon exchange rate. Carbon exchange rate was measured on a terminal leaflet of mature petioles at midday with a photosynthesis system (model LI-6000; LI-COR, Lincoln, Neb.) and leaf area was measured with a leaf area meter (LI-3000A; LI-COR).

Enzyme extraction. Frozen celery tissue was ground in a chilled mortar using a 1 tissue : 4 buffer ratio. Buffer contained $50 \mathrm{~mm}$ Mops-NaOH (pH 7.5), 5 mm $\mathrm{MgCl}_{2}, 5$ mm DTT, 1 mм EDTA, and $1 \%(\mathrm{v} / \mathrm{v})$ Triton X-100 for the sucrose-phosphate-synthase (SPS), sucrose synthase (SS), acid- and neutral invertase activities (AI, $\mathrm{NI}$ ), and phosphomannose isomerase (PMI) assays . For the hexokinase assay, tissue was ground in $50 \mathrm{~mm}$ Hepes- $\mathrm{NaOH}(\mathrm{pH}$ 8.0), $5 \mathrm{~mm} \mathrm{MgCl}_{2}, 2.5 \mathrm{~mm}$ DTT, $1 \mathrm{~mm}$ EDTA , $0.5 \mathrm{mg} \mathrm{BSA} / \mathrm{ml}$, and $1 \%(\mathrm{v} / \mathrm{v})$ Triton X-100. For the UDP-glucose pyrophosphorylase (UDP-Glc PPase) assay, tissue was ground in $50 \mathrm{~mm}$ Mops-NaOH (pH 7.5), 5 mM MgCl, 2.5 mm DTT, 1 mm EDTA, 0.5 mg/ml BSA and $0.05 \%(\mathrm{v} / \mathrm{v})$ Triton X-100. Homogenates were centrifuged at $10,000 \times g$ for $1 \mathrm{~min}$. Supernatants were desalted immediately by centrifugal filtration on columns (Sephadex G-25-50; Sigma, St. Louis) equilibrated with the grinding buffer lacking EDTA and Triton X-100.

Enzyme assays. Assays for SPS, SS, AI, and NI were conducted as described by Hubbard et al. (1990). The PMI assay contained the following reaction mixture: $100 \mathrm{~mm} \mathrm{Hepes} \mathrm{(} \mathrm{pH} 7.5), 5 \mathrm{~mm} \mathrm{MgCl}$, $0.5 \mathrm{~mm} \mathrm{NAD}^{+}, 7.5 \mathrm{U}$ glucose-6-phosphate dehydrogenase $/ \mathrm{ml}$, and $6.0 \mathrm{U}$ phosphoglucose isomerase $/ \mathrm{ml}$; the reaction was initiated with $2.5 \mathrm{~mm}$ mannose-6-phosphate. The UDP-Glc PPase assay mixture contained 50 mм Hepes- $\mathrm{NaOH}$ (pH 7.0), $2 \mathrm{~mm} \mathrm{MgCl}, 1$ mM EDTA, 0.4 mm NAD ${ }^{+}, 2$ U glucose-6-phosphate dehydrogenase/ml, $2 \mathrm{U}$ phosphoglucomutase/ml, and $1 \mathrm{~mm}$ UDP-Glc and was initiated with $1 \mathrm{~mm}$ PPi. The mannokinase assay mix contained $50 \mathrm{~mm}$ Hepes (pH 8.0), $1 \mathrm{~mm} \mathrm{MgCl}, 1 \mathrm{~mm}$ ATP, $1 \mathrm{~mm}$ $\mathrm{NAD}^{+}, 2 \mathrm{U} / \mathrm{ml}$ phosphoglucose isomerase, 2 U glucose-6-phosphate dehydrogenase $/ \mathrm{ml}$, and $2 \mathrm{U}$ phosphomannose isomerase $/ \mathrm{ml}$, and was initiated with $10 \mathrm{~mm}$ D-mannose. The fructokinase assay mix contained 50 mm Hepes ( $\mathrm{pH} 8.0$ ), $1 \mathrm{~mm} \mathrm{MgCl}, 1 \mathrm{~mm}$ ATP, 1 mM NAD ${ }^{+}, 2 \mathrm{U} / \mathrm{ml}$ phosphoglucose isomerase, 2 U glucose-6phosphate dehydrogenase $/ \mathrm{ml}$, and $50 \mathrm{~mm} \mathrm{KCl}$, and was initiated with $0.5 \mathrm{~mm}$ D-fructose.

Statistical analysis. In the first experiment, treatments consisted of two culture systems (growth substrates), Promix and hydroponic. Each treatment was replicated four times and eight plants were harvested at five intervals (weeks $2,4,6,8$, or 12). Two plants per replication were analyzed. In the second experiment, treatments consisted of plants grown hydroponically at two different nutrient strengths, Hydroponic-1X and Hydroponic-3X. Each treatment was replicated four times and eight plants (two plants per replication) were harvested at week 12 . The data were analyzed using the analysis of variance and general linear model procedures of the statistical analysis system (SAS Institute, Cary, N.C.).

\section{Results}

Celery plants grown in a hydroponic container system for 12 weeks did not differ in growth and development from plants grown in Promix. Promix- and hydroponically grown plants did not differ in shoot fresh weight (Fig. 1A) or number of petioles per plant (Fig. 1B) during the experiment, except for week 12, during which hydroponically grown plants had a slightly heavier shoot. The $\mathrm{C}$ exchange rate of fully expanded leaves of Promix- and hydroponically grown plants did not differ greatly (Fig. 1C, insert), and the photosynthetic rate depended on the developmental stage of the leaf, with fully expanded leaves having the highest $C$ exchange rate (Fig. 1C). The leaf area of individual petioles was not affected by the growth substrate (Fig. 1D). The latter, together with the $\mathrm{C}$ exchange data, indicated that the capacity of $\mathrm{CO}_{2}$ assimilation was similar in plants grown in the different culture systems. Because petioles of celery plants emerge from the center of the plant to form a rosette, plants consist of a range of petioles at different stages of development. Plants were harvested at week 2, 4, 6, 8, or 12 and growth of individual petioles was monitored.

Petioles of 8-week-old Promix- and hydroponically grown 

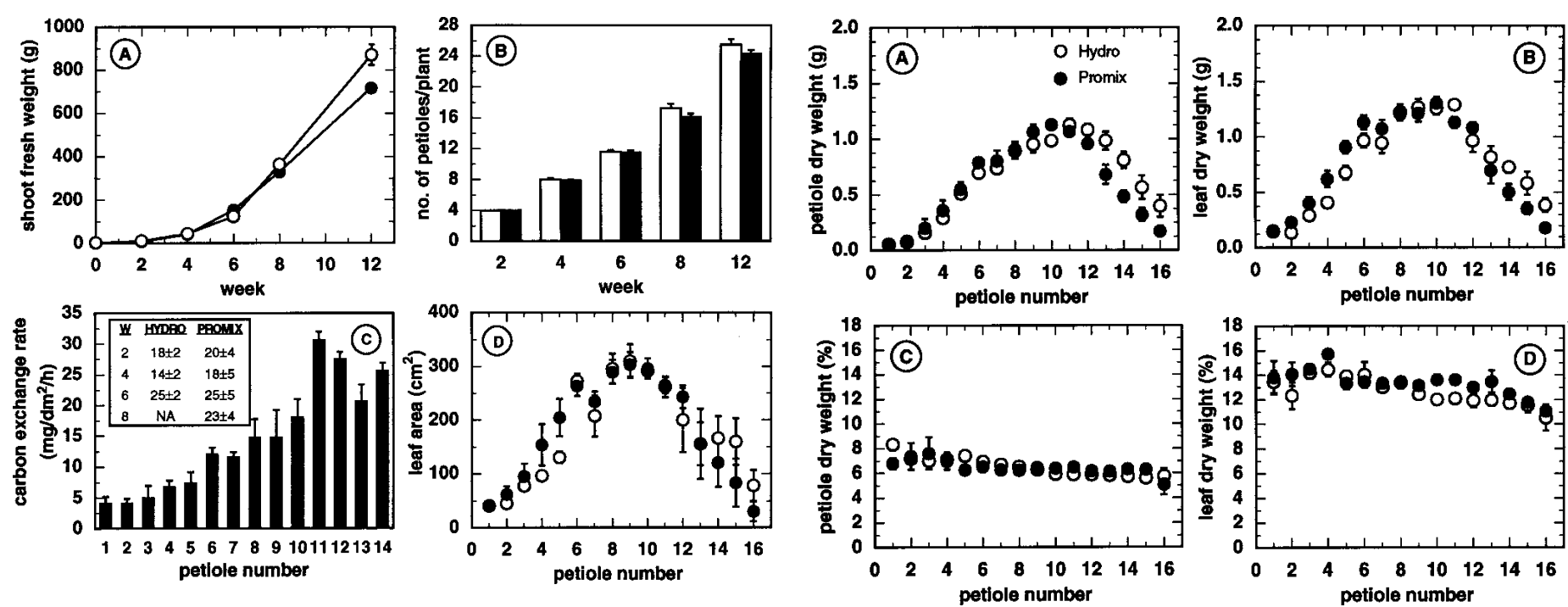

Fig. 1. Fresh weight of the shoot $(\mathbf{A})$ and total number of petioles per plant $(\mathbf{B})$ of Promix- $(\mathbf{)}$ and hydroponically $(\bigcirc)$ grown celery. Carbon exchange rate of celery leaves of Promix-grown plants $(\mathbf{C})$. Insert in $\mathbf{C}$ represents $\mathbf{C}$ exchange rate of fully expanded celery leaves, measured under ambient conditions over 8 weeks. PPFD values ranged from 300 to $1500 \mu \mathrm{mol} \cdot \mathrm{m}^{-2} \cdot \mathrm{s}^{-1}$ on different sampling dates. NA= not analyzed. The hydroponic solution was composed of a Hydroponic-1X nutrient solution (see Materials and Methods). Leaf area of petioles from 8-week-old Promix- ()$_{)}$and hydroponically $(\bigcirc)$ grown celery plants (D). Petioles were numbered from the outside to the inside of the plant, with petiole 1 being the oldest petiole. Each datum represents the mean \pm SE of four replications.

plants did not differ in petiole dry weight (Fig. 2A), leaf dry weight (Fig. 2B), percentage dry weight of the petiole (Fig. 2C), and percentage dry weight of the leaf (Fig. 2D). No statistical differences were observed in petiole or leaf fresh weight of plants grown in Promix or hydroponics (data not shown). A more extensive analysis of variance including data from week $2,4,6,8$, and 12 also revealed no statistical differences in plant growth attributable to growth substrate. Furthermore, no interactive effect of week and growth substrate on plant growth was observed.

The effect of growth substrate on $\mathrm{C}$ partitioning in celery petioles was determined by comparing the total soluble carbohydrate (hexose plus sucrose plus mannitol), hexose, sucrose, and mannitol concentrations in Promix- and hydroponically grown celery plants. The total soluble carbohydrate concentration of petioles from Promix- and hydroponically grown plants was similar for 8 weeks after transplanting and was slightly higher for Promix-grown plants at week 12 (Fig. 3A). However, a distinct difference in the ratio of mannitol to hexose concentration was observed. The ratio of mannitol to hexose concentration in petioles was $\approx 2$-fold higher for hydroponically grown plants compared to Promix-grown plants (Fig. 3B). This relationship was maintained during the entire experimental period. At week 8, petioles of Promix- and hydroponically grown celery did not differ in total soluble carbohydrate concentration (Fig. 4A). However, growth substrate had a distinct effect on the individual mannitol, sucrose and hexose concentrations. Hydroponically grown plants contained higher mannitol (Fig. 4B), lower sucrose (Fig. 4C), and lower hexose concentrations (Fig. 4D) compared to Promix-grown plants. The largest differences were observed in petioles that developed after transplanting (petioles five to 17).

Promix- and hydroponically grown plants differed in the activities of several carbohydrate metabolizing enzymes (Table 1). Young petioles of Promix-grown plants had a higher mannokinase, hexokinase, PMI, UDP-Glc PPase, SPS, SS, and AI activity compared to hydroponically grown plants. Mature petioles of

Fig. 2. Petiole dry weight (A), leaf dry weight (B), percentage dry weight of the petiole $(\mathbf{C})$, and percentage dry weight of the leaf $(\mathbf{D})$ of petioles from 8-weekold Promix- $(\bullet)$ and hydroponically $(\bigcirc)$ grown celery . Each datum represents the mean \pm sE of four replications.
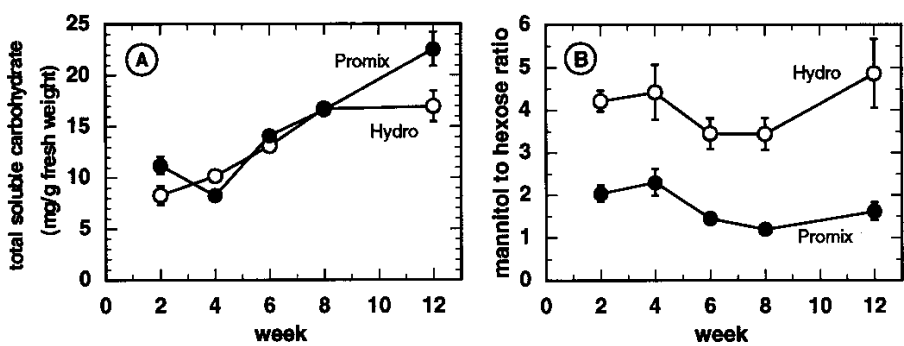

Fig. 3. Total soluble carbohydrate (glucose plus fructose plus sucrose plus mannitol) concentration of petioles (A) and ratio of mannitol to hexose concentration of petioles (B) of Promix- (Promix) and hydroponically (Hydro-) grown celery. The hydroponic solution was composed of a Hydroponic-1X nutrient solution (see Materials and Methods). Each datum represents the mean \pm SE of four replications. Analysis includes all petioles except senescent ones.
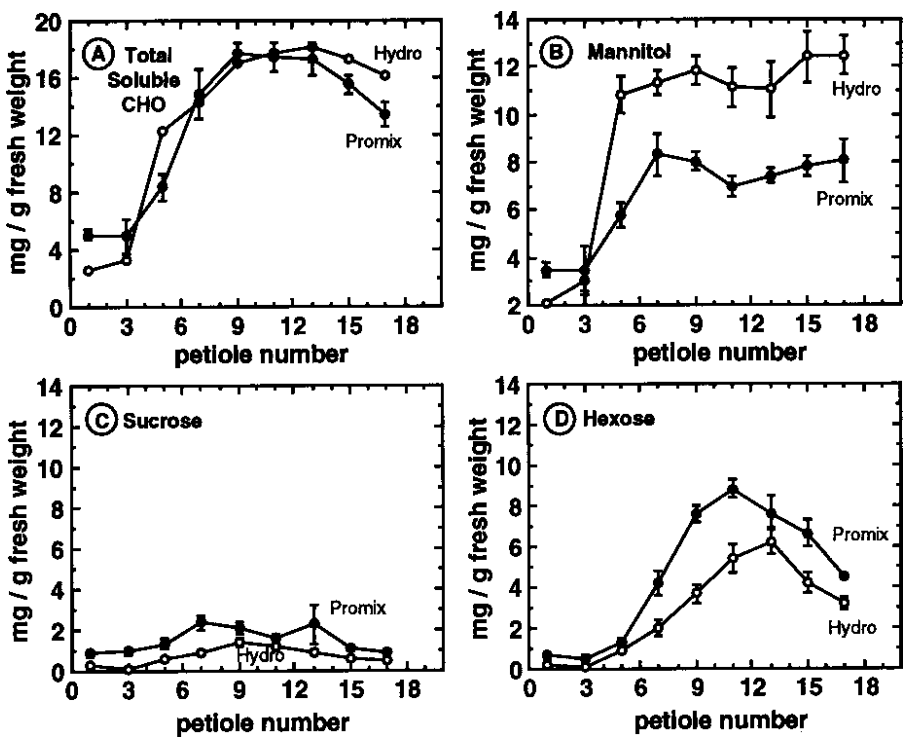

Fig. 4. Total soluble carbohydrate (glucose plus fructose plus sucrose plus mannitol) (A), mannitol (B), sucrose (C), and hexose (D) concentrations of petioles of 8week-old, Promix- (Promix) and hydroponically (Hydro-) grown celery. The hydroponic solution was composed of a Hydroponic-1X nutrient solution (see Materials and Methods). Petioles were numbered from the outside to the inside of the plant, with petiole 1 being the oldest petiole. Each datum represents the mean \pm SE of four replications. 
Promix-grown plants had a higher PMI, UDP-Glc PPase, SPS, and AI, whereas old, senescent petioles did not differ in enzyme activities compared to hydroponically grown plants. Neutral invertase was not affected by the growth substrate. At the time of petiole harvest, petioles were frozen in liquid $\mathrm{N}_{2}$ and stored at $-80 \mathrm{C}$ for several weeks before being assayed for enzyme activity. Under these experimental conditions, no mannitol dehydrogenase could be detected. However, recently we isolated and purified a NADdependent mannitol 1-oxidoreductase from celeriac [Apium graveolens L. var. rapaceum (Mill.) Gaud] roots, which catalyzes the oxidation of mannitol to mannose (Stoop and Pharr, 1992). This enzyme was found in celery and was highly active in sinks (roots and young petioles) and was less active in mature petioles of celery (Stoop and Pharr, 1993).

Carbohydrate partitioning and enzyme activities were both affected by petiole development within the plant. Regardless of the growth substrate, total soluble carbohydrate and mannitol concentration were high in mature and young petioles (at week 8, petiole nine to 17) (Fig. 4 A and B), whereas hexose and sucrose concentrations were highest in mature petioles (at week 8, petiole nine to 13) (Fig. 4 C and D). The hexose pool was comprised of equimolar glucose and fructose concentrations in all petioles (data not shown). All carbohydrate metabolizing enzyme activities differed markedly in petioles of different developmental stages, with the highest activities observed in the youngest (sink) tissues (Table 1).

It is clear that the growth substrate or culture condition (Promix vs. hydroponics) affects the carbohydrate composition of the celery petiole, and in particular the mannitol and hexose concentrations. The Promix and hydroponic culture systems differed in several components, such as physical properties of the substrates and the mineral composition and total salt concentration of the nutrient solution applied. The total salt concentration, as measured by EC, of the nutrient solution applied once a week to Promixgrown plants was $1.8 \mathrm{mS} \cdot \mathrm{cm}^{-1}$, whereas the $\mathrm{EC}$ of the nutrient solution used in the hydroponic culture was $2.7 \mathrm{mS} \cdot \mathrm{cm}^{-1}$. Because mannitol plays an important physiological role in protecting plants against salt stress (Tarczynski et al., 1993), one can hypothesize that the total salt concentration of the nutrient solution might affect mannitol and hexose concentrations in celery petioles. To test the hypothesis that $\mathrm{C}$ partitioning within the celery petiole could be altered by increased nutrient concentrations in the root environment, celery transplants were grown in Hydroponic-1X $(\mathrm{EC}=2.7$ $\left.\mathrm{mS} \cdot \mathrm{cm}^{-1}\right)$ and Hydroponic-3X $\left(\mathrm{EC}=6.0 \mathrm{mS} \cdot \mathrm{cm}^{-1}\right)$ mineral solutions (see Materials and Methods). Eight weeks after transplanting, plants grown at $\mathrm{EC}=2.7$ or $6.0 \mathrm{mS} \cdot \mathrm{cm}^{-1}$ had similar root fresh weight ( $55 \pm 2$ and $64 \pm 13 \mathrm{~g}$, respectively) and shoot fresh weight (336 \pm 11 and $305 \pm 32 \mathrm{~g}$, respectively). At week 12, the root fresh weight of plants grown in Hydroponic-3X $(152 \pm 11 \mathrm{~g})$ was similar to that of Hydroponic-1X-grown plants (146 $\pm 11 \mathrm{~g}$ ), while the fresh weight of the shoot was slightly higher for Hydroponic-1Xgrown plants $(870 \pm 47 \mathrm{~g})$ compared to Hydroponic-3X-grown plants $(721 \pm 26 \mathrm{~g})$. Although the total soluble carbohydrate concentration was slightly higher in Hydroponic-3X-grown plants (Fig. 5A), the major effect of salt concentration was observed in the mannitol pool (Fig. 5B). Mature and young celery petioles of plants grown for 12 weeks at the higher salt concentration contained a higher mannitol pool (Fig. 5B) together with a lower hexose pool (Fig. 5C) compared to the Hydroponic-1X-grown plants. A higher mannitol-to-hexose ratio was observed in petioles of plants grown at the higher salt environment $\left(\mathrm{EC}=6.0 \mathrm{mS} \cdot \mathrm{cm}^{-1}\right)$, except for the very innermost petiole (Fig. 5D). These results were analogous to those observed in the first experiment and indicate that differences in salt concentration in the root environment can affect the carbohydrate pool of celery petioles without markedly affecting whole-plant growth.
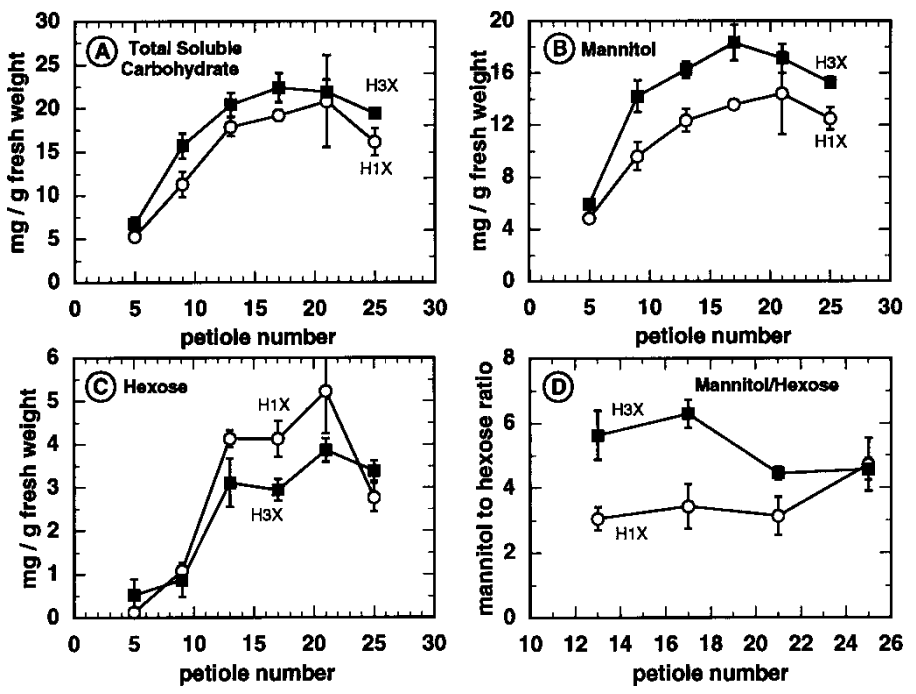

Fig. 5. Total soluble carbohydrate (glucose plus fructose plus sucrose plus mannitol) (A), mannitol (B), and hexose (C) concentration and ratio of mannitol to hexose concentration (D) of petioles of 12-week-old celery plants grown in Hydroponic-1X (H1X) or Hydroponic-3X (H3X) nutrient solution. See Materials and Methods.

Table 1. Activities of carbohydrate-metabolizing enzymes extracted from old, mature, and young petioles of 8-week-old Promix- or hydroponically (Hydro-) grown celery.

\begin{tabular}{|c|c|c|c|c|c|c|}
\hline \multirow[b]{2}{*}{ Enzyme $^{z}$} & \multicolumn{2}{|c|}{ Old petiole } & \multicolumn{2}{|c|}{ Mature petiole } & \multicolumn{2}{|c|}{ Young petiole } \\
\hline & Promix & Hydro & Promix & Hydro & Promix & Hydro \\
\hline \multicolumn{7}{|c|}{$\mu \mathrm{mol} \cdot h^{-1} \cdot \mathrm{g}^{-1}$ fresh $w t$} \\
\hline Mannokinase & $1.7 \pm 0.2^{y}$ & $2.0 \pm 0.2$ & $2.9 \pm 0.2$ & $3.0 \pm 0.4$ & $5.8 \pm 0.2$ & $3.9 \pm 0.4$ \\
\hline Hexokinase & $3.4 \pm 0.3$ & $3.8 \pm 0.3$ & $6.0 \pm 0.3$ & $5.6 \pm 0.3$ & $12.8 \pm 1.0$ & $10.5 \pm 0.2$ \\
\hline PMI & $34.3 \pm 5.9$ & $32.0 \pm 2.5$ & $42.8 \pm 1.6$ & $37.2 \pm 3.5$ & $58.7 \pm 0.4$ & $41.6 \pm 1.1$ \\
\hline UDP-Glc PPase & $140.0 \pm 19.0$ & $140.0 \pm 21.0$ & $415.0 \pm 24.0$ & $324.0 \pm 27.0$ & $1127 \pm 156$ & $829.0 \pm 36.0$ \\
\hline SPS & $2.7 \pm 1.6$ & $1.0 \pm 0.8$ & $5.8 \pm 0.4$ & $2.3 \pm 0.8$ & $11.1 \pm 2.5$ & $4.8 \pm 0.5$ \\
\hline SS & $2.0 \pm 0.9$ & $2.0 \pm 0.9$ & $3.7 \pm 0.4$ & $3.4 \pm 1.0$ & $12.6 \pm 1.2$ & $7.0 \pm 1.6$ \\
\hline AI & $2.6 \pm 0.4$ & $1.9 \pm 0.6$ & $20.3 \pm 5.5$ & $5.0 \pm 2.5$ & $39.7 \pm 8.1$ & $27.1 \pm 3.8$ \\
\hline NI & $2.3 \pm 0.3$ & $1.8 \pm 1.1$ & $4.8 \pm 0.6$ & $3.9 \pm 0.5$ & $11.4 \pm 2.6$ & $9.6 \pm 1.3$ \\
\hline
\end{tabular}

ㄱMI = phosphomannose isomerase; UDP-Glc PPase = UDP-glucose pyrophosphorylase; SPS = sucrose phosphate synthase; SS = sucrose synthase; $\mathrm{AI}=$ acid invertase $; \mathrm{NI}=$ neutral invertase.

${ }^{\mathrm{y}}$ Mean \pm SE of four replications. 


\section{Discussion}

To study the effect of environmental variables such as salt or osmotic stress on plant growth and development, it is beneficial if the crop can be grown hydroponically. Hydroponic culture systems such as the nutrient film technique or container culture allow easy access to root systems and have proven to be very useful in studies in which the root environment needs to be under tight control (Benoit et al., 1986; Tarczynski et al., 1993).

The results of these studies indicate that celery grown in the soilless mixture Promix did not differ in growth and development from hydroponically grown celery, as was evident from dry weight and fresh weight data. However, the growth substrate had a distinct effect on the mannitol and hexose concentrations of celery petioles, without affecting their total soluble carbohydrate concentration. The ratio of mannitol to hexose in celery petioles was 2-fold higher in hydroponically grown plants compared to Promix-grown plants. The Promix and hydroponic culture system differed in several components such as physical properties of the substrates, the mineral composition, and total salt concentration of the nutrient solution applied. A higher salt concentration in the root environment of hydroponically grown plants $\left(\mathrm{EC}=2.7 \mathrm{mS} \cdot \mathrm{cm}^{-1}\right)$ compared to Promix-grown plants $\left(\mathrm{EC}=1.8 \mathrm{mS} \cdot \mathrm{cm}^{-1}\right)$ might be responsible for the observed differences in mannitol-to-hexose ratios. When celery plants were grown hydroponically at two different salt levels, EC 2.7 and $6.0 \mathrm{mS} \cdot \mathrm{cm}^{-1}$, a higher mannitol-tohexose ratio was observed in plants grown at the higher EC, a result supporting the above hypothesis. Celery differs from sucrose translocating and raffinose saccharide translocating plants in that sucrose and the sugar alcohol mannitol are the major photosynthetic assimilates that are translocated in the phloem to sink and storage tissues. Recent experiments support a role for mannitol as an osmoregulator and a compatible solute. Polyols such as mannitol may function as compatible solutes by replacing water molecules, thereby preserving hydration of the cytoplasmic biopolymers of stressed plants (Schobert, 1977). Polyols may also protect cells by scavenging hydroxyl radicals (Smirnoff and Cumbes, 1989). Mannitol concentrations in leaves and roots of pot-grown celery plants increased in response to increased $\mathrm{NaCl}$ applications (Everard et al., 1992). Tarczynski et al. (1993) used a hydroponic system to study salt tolerance of wild-type and transformed tobacco plants encoding the Escherichia coli gene mannitol-1phosphate dehydrogenase (Tarczynski et al., 1992). and demonstrated that the mannitol producing transgenic tobacco plant exhibited increased salt tolerance.

Differences in $\mathrm{C}$ partitioning between mannitol and hexose could be due to metabolism of mannitol within the celery petiole. Other factors might also affect $\mathrm{C}$ partitioning, such as diminished accumulation or use of mannitol in the root, resulting in increased mannitol accumulation in the shoot, differences in the ratio of mannitol to sucrose supplied to the petioles by the leaves, or differences in phloem unloading of mannitol and sucrose into the petioles of Promix- and hydroponically grown plants. Although it is impossible to exclude any of the above hypotheses based on the data presented here, patterns of sugar-metabolizing enzymes suggest that celery petioles might be able to metabolize mannitol by converting it to glucose and fructose through a sucrose intermediate. Mannitol oxidation to mannose is catalyzed by a NADdependent 1-oxidoreductase, which is present in sink tissue (Stoop and Pharr, 1992). Mannose can be phosphorylated to mannose-6$\mathrm{P}$ by the action of a hexokinase, and further isomerized to fructose6-P by the action of PMI. Celery petioles had very high PMI activities ( 0.7 to $1.0 \mu \mathrm{mol} \cdot \mathrm{min}^{-1} \cdot \mathrm{g}^{-1}$ fresh weight) compared to nonlegume seeds $\left(0.06 \mu \mathrm{mol} \cdot \mathrm{min}^{-1} \cdot \mathrm{g}^{-1}\right.$ fresh weight) (McCleary and Matheson, 1976) and konjac corms $\left(0.07 \mu \mathrm{mol} \cdot \mathrm{min}^{-1} \cdot \mathrm{g}^{-1}\right.$ fresh weight) (Murata, 1975), legume seeds $\left(0.024\right.$ to $1.8 \mu \mathrm{mol} \cdot \mathrm{min}^{-1} \cdot \mathrm{g}^{-1}$ fresh weight) (McCleary and Matheson, 1976), and Lilium bulbs $\left(0.3 \mu \mathrm{mol} \cdot \mathrm{min}^{-1} \cdot \mathrm{g}^{-1}\right.$ fresh weight $)$ (Miller, 1989). This might indicate that PMI of celery petioles plays an important role in mannose-6-P metabolism and, indirectly, in mannitol catabolism. Different salt concentrations in the root environment might affect the catabolism of mannitol and thus influence the mannitol-tohexose concentrations providing an adaptive mechanism to the increased salt environment.

These experiments show that environmental growth conditions, such as different growth substrates or total salt concentration of nutrient solution, can markedly influence soluble assimilate partitioning within celery petioles without affecting plant growth and development. Furthermore, some evidence was presented supporting the hypothesis that mannitol levels may be an important component of plant adjustment to elevated salt stress. Mannitol may be involved in osmoprotection by acting as a compatible solute, as plants grown in a higher EC nutrient solution did not differ in growth and development but accumulated mannitol in petiole tissue.

\section{Literature Cited}

Ahmad, I., F. Larher, and G.R. Stewart. 1979. Sorbitol, a compatible osmotic solute in Plantago maritima. New Phytol. 82:671-678.

Barker, S.A. 1955. Acyclic sugar alcohols, p. 55-63. In: K. Paech and M.V. Tracey (eds.). Modern methods of plant analysis. vol. 2. Springer, Berlin.

Benoit, F., D. Lamberts, and C. Van Assche. 1986. Grondloze teelten. Instituut tot Aanmoediging van het Wetenschapplijk Onderzoek in Nijverheid en Landbouw, Belgium.

Bieleski, R.L. 1982. Sugar alcohols, p. 158-192. In: F.A. Loewus and W. Tanner (eds.). Plant carbohydrates I. Intracellular carbohydrates. Encyclopedia of plant physiology. vol. 13A. new series. Springer-Verlag, New York.

Bourne, E.J. 1958. The polyhydric alcohols. Acyclic polyhydric alcohols, p. 345-362. In: W. Ruhland (ed.). Encyclopedia of plant physiology. vol. 6, Springer-Verlag, Berlin.

Brown, A.D. and J.R. Simpson. 1972. Water relations of sugar-tolerant yeasts: The role of intracellular polyols. J. Gen. Microbiol. 72:589-591.

Davis, J.M., J.K. Fellman, and W.H. Loescher. 1988. Biosynthesis of sucrose and mannitol as a function of leaf age in celery (Apium graveolens L.). Plant Physiol. 86:129-133.

Everard, J.D., S.C. Kann, and W.H. Loescher. 1992. Investigations into the salt tolerance of the mannitol producer celery. Plant Physiol. 99:28. (Abstr.)

Greenway, H. and R. Munns. 1980. Mechanisms of salt tolerance in nonhalophytes. Annu. Rev. Plant Physiol. 31:149-190.

Hellebust, J.A. 1976. Osmoregulation. Annu. Rev. Plant Physiol. 27:485505 .

Hubbard, N.L., D.M. Pharr, and S.C. Huber. 1990. Sucrose metabolism in ripening muskmelon fruit as affected by leaf area. J. Amer. Soc. Hort. Sci. 115:798-802.

Lewis, D.H. 1984. Physiology and metabolism of alditols, p. 143-184. In: D.H. Lewis (ed.). Storage carbohydrates in vascular plants. Cambridge Univ. Press, Cambridge.

Loescher, W.H., R.H. Tyson, J.D. Everard, R.J. Redgwell, and R.L. Bieleski. 1992. Mannitol synthesis in higher plants. Evidence for the role and characterization of a NADPH-dependent mannose-6-phosphate reductase. Plant Physiol. 98:1396-1402.

Loescher, W.H. 1987. Physiology and metabolism of sugar alcohols in higher plants. Physiol. Plant. 70:553-557.

McCleary, B.V. and N.K. Matheson. 1976. Galactomannan utilization in germinating legume seeds. Phytochemistry 15:43-47.

Miller, W.B. 1989. Identification of free mannose and partial purification 
of a mannose-6-phosphate isomerase from Lilium longiflorum bulbs. Physiol. Plant. 77:123-128.

Murata, T. 1975. Studies on the phosphomannose isomerase of Amorphophallus konjac C. Koch. I. Its isolation and some enzymic properties. Plant Cell Physiol. 16:953-961.

Rumpho, M.E., G.E. Edwards, and W.H. Loescher. 1983. A pathway for photosynthetic carbon flow to mannitol in celery leaves. Activity and localization of key enzymes. Plant Physiol. 73:869-873.

Schobert, B. 1977. Is there an osmotic regulatory mechanism in algae and higher plants? J. Theoretical Biol. 68:17-26.

Smirnoff, N. and Q.J. Cumbes. 1989. Hydroxyl radical scavenging activity of compatible solutes. Phytochemistry 28:1057-1060.

Stacey, B.E. 1974. Plant Polyols, p. 47-59. In: J.B. Pridham (ed.). Plant carbohydrate biochemistry. Academic Press, New York.

Stoop, J.M.H. and D.M. Pharr. 1992. Partial purification and characterization of mannitol:mannose 1-oxidoreductase from celeriac (Apium graveolens var. rapaceum) roots. Arch. Biochem. Biophys. 298:612-619.

Stoop, J.M.H. and D.M. Pharr. 1993. Possible role of mannitol 1oxidoreductase in celery sink tissue. HortScience 28:534. (Abstr.)
Tarczynski, M.C., R.G. Jensen, and H.J. Bohnert. 1992. Evaluation of the concept of osmoprotection: effect of mannitol production in transgenic tobacco. Plant Physiol. 99:27. (Abstr.)

Tarczynski, M.C., R.G. Jensen, and H.J. Bohnert. 1993. Salt protection of transgenic tobacco by production of the osmolyte mannitol. Science 259:508-510.

Trip, P., G. Krotkov, and C.D. Nelson. 1963. Biosynthesis of mannitol-C ${ }^{14}$ from $\mathrm{C}^{14} \mathrm{O}_{2}$ by detached leaves of white ash and lilac. Can. J. Bot. 41:1005-1010.

Trip, P., G. Krotkov, and C.D. Nelson. 1964. Metabolism of mannitol in higher plants. Amer. J. Bot. 51:828-835.

Yancey, P.H, M.E. Clark, S.C. Hand, R.D. Bowlus, and G.N. Somero. 1982. Living with water stress: Evolution of osmolyte systems. Science 217: 1214-1222.

Zimmermann, M.H. and H. Ziegler. 1975. List of sugars and sugar alcohols in sieve-tube exudates, p. 408-503. In: M.H. Zimmermann and J.A. Milburn (eds.). Transport in plants. I. Phloem transport. Encyclopedia of plant physiology. vol. 1. new series. Springer-Verlag, New York. 